DOI: $10.19195 / 0137-1134.107 .13$

\author{
MARTA STATKIEWICZ
}

Uniwersytet Wrocławski

\title{
KSIĄŻKA JAKO PRZEDMIOT REALIZACJI WARTOŚCI KULTUROWYCH W UNII EUROPEJSKIEJ
}

\section{WPROWADZENIE}

Dyskusja nad potrzebą uznania wartości kulturowych niektórych towarów w wybranych obszarach prawa ${ }^{1}$ została zapoczątkowana wyrokiem brytyjskiego sądu antymonopolowego z 1962 roku w sprawie Net Book Agreement, w którym sędzia Buckley orzekł: „Książki są inne”2. Książki jako dzieła kultury, które są przede wszystkim towarami podlegającymi zasadom obrotu gospodarczego, stały się pierwszym widocznym przykładem napięć między potrzebą ochrony różnorodności kulturowej a swobodą gospodarczą w Europie. Ich szczególny charakter po raz pierwszy został sformułowany w rezolucji Parlamentu Europejskiego z dnia 13 lutego $1981 \mathrm{roku}^{3}$. Uznano w niej, że handel książkami nie powinien opierać się wyłącznie na kryteriach ekonomicznych, gdyż bezpośrednio wpływa na zainteresowanie obywateli w dziedzinie kultury, edukacji oraz informacji. Każde państwo członkowskie ma prawo swobodnego wyboru środków służących promocji książek i czytelnictwa, jednak zgodnie z decyzją Rady z dnia 22 września 1997 roku $^{4}$ należy dążyć do zrównoważenia jej kulturalnych i gospodarczych aspektów.

Książka w prawie Unii Europejskiej ma podwójny charakter — jest zarówno przedmiotem transakcji, jak i nośnikiem wartości kulturowych. Zgodnie z rezolucją Rady z dnia 12 lutego 2001 roku$^{5}$ jej szczególna wartość jako dzieła kultury

1 V. Kitz, The difference between books and chocolate bars - How EC Treaty art. 151(4) affects Community actions, „AIPLA Quarterly Journal” 32, 2004, nr 3, s. 363.

2 S. Kurschus, European Book Cultures: Diversity as a Challange, Wiesbaden 2015, s. 261.

3 Rezolucja Parlamentu Europejskiego z dnia 13 lutego 1981 r. w sprawie ustalania cen książek, 51980 IP0554.

${ }^{4}$ Decyzja Rady nr 97/C 305/02 z 22 września 1997 r. w sprawie transgranicznych stałych cen książek w europejskich obszarach lingwistycznych, 31997D1007(02).

5 Rezolucja Rady nr 73/03 z 12 lutego 2001 r. o stosowaniu krajowych systemów sztywnych cen książek, 32001G0306(02). 
powinna być uwzględniana w przypadku stosowania unijnych reguł konkurencji czy zasad swobodnego przepływu towarów.

Znaczenie książek dla zachowania i promowania różnorodności kulturowej w Unii Europejskiej miało wpływ na utworzenie specjalnych mechanizmów jej wsparcia i ochrony, które stanowią główny problem badawczy artykułu. Unijne przepisy z zakresu opodatkowania, reguł konkurencji, a także prawa autorskiego i praw pokrewnych umożliwiły państwom członkowskim szczególne traktowanie książek jako towarów, podkreślając przy tym ich kulturowy charakter. $Z$ tego powodu zakres badawczy artykułu obejmuje te gałęzie prawa unijnego, które wpływają na krajowe regulacje w tym zakresie. Niezależnie od gospodarczego charakteru książki są przede wszystkim wynikiem twórczości artystycznej i literackiej, która zgodnie z art. 167 Traktatu o funkcjonowaniu Unii Europejskiej (TFUE) podlega unijnemu wsparciu i uzupełnieniu działań państw członkowskich w dziedzinie kultury. Mechanizmy omówione w poniższym artykule mają na celu podkreślenie wartości kulturowych książek oraz umożliwiają ich specjalne traktowanie w obrocie towarowym na rynku wewnętrznym Unii Europejskiej.

\section{KULTURA W PRAWIE UNII EUROPEJSKIEJ}

Traktaty założycielskie koncentrujące się na celach ekonomicznych traktowały kulturę jako dziedzinę niegospodarczą ${ }^{6}$, która znajdowała się poza kompetencjami wspólnotowymi. Niemniej jednak przekonanie, iż eliminacja barier w handlu będzie miała konsekwencje dla europejskiej kultury, było powszechnie znane $^{7}$. Wskutek powiązania aspektów kulturowych z ekonomicznymi instytucje Wspólnot coraz częściej zaczęły podejmować tę problematykę. Kompetencje do działania w zakresie kultury zostały ustanowione dopiero traktatem z Maastricht ${ }^{8}$, choć samo pojęcie nie zostało do tej pory zdefiniowane?

Analizując aktualne regulacje związane z kulturą w prawie Unii Europejskiej, rozważania nad tą problematyką należy rozpocząć od zbadania wybranych postanowień traktatów ${ }^{10}$. Zgodnie z art. 3 TUE poszanowanie bogatej różnorodności

6 A. Wyrozumska, Kultura, [w:] Prawo Unii Europejskiej. Zagadnienia systemowe. Prawo materialne i polityki, red. J. Barcz, Warszawa 2016, s. II-567.

7 C.B. Cunningham, In Defense of Memer State Culture: The Unrealized Potential of Article 151(4) of the EC Treaty and the Consequence for EC Cultural Policy, „Cornell International Law Journal" 34, 2001, s. 121.

8 Art. 128 TWE, następnie art. 151 TWE wskutek zmian wprowadzonych Traktatem amsterdamskim.

9 A. Wyrozumska, op. cit., s. II-568.

10 Traktatu o Unii Europejskiej (dalej: TUE) oraz Traktatu o funkcjonowaniu Unii Europejskiej. 
kulturowej i językowej Unii oraz czuwanie nad ochroną i rozwojem dziedzictwa kulturowego jest jednym z głównych celów Unii Europejskiej. Kultura znalazła się również w katalogu kompetencji realizowanych przez Unię na podstawie art. 6 TFUE, zgodnie z którym ma kompetencje do prowadzenia działań mających na celu wspieranie, koordynowanie lub uzupełnianie aktywności państw członkowskich. Jej zadaniem jest, wedle zasady subsydiarności, wspomaganie działań państw, lecz w żadnym wypadku nie zastępuje ich w kreowaniu własnej polityki kulturalnej ${ }^{11}$.

Najważniejszą regulacją związaną z traktatową kompetencją Unii do działania w dziedzinie kultury jest art. 167 TFUE. Umożliwia on Unii przyczynianie się do rozkwitu kultur państw członkowskich przy jednoczesnym respektowaniu ich narodowych i regionalnych różnorodności (art. 167 ust. 1 TFUE), a także sprzyjanie współpracy z państwami trzecimi oraz organizacjami międzynarodowymi (art. 167 ust. 3 TFUE). Działania UE w związku z powyższym zmierzają do zachęcania do współpracy między państwami członkowskimi w zakresie pogłębiania wiedzy i upowszechniania kultury oraz historii; ochrony dziedzictwa kulturowego; niehandlowej wymiany kulturalnej oraz twórczości artystycznej, literackiej i audiowizualnej (art. 167 ust. 2 TFUE). Warto zaznaczyć, że art. 167 TFUE zawiera także normę kompetencyjną dla Parlamentu i Rady, które mogą przyjmować środki zachęcające w celu uzupełnienia działań podejmowanych przez państwa członkowskie, z wyłączeniem jakiejkolwiek harmonizacji przepisów ustawowych, a także umożliwia Radzie wydawanie zaleceń na wniosek Komisji (art. 167 ust. 5 TFUE). Przykładem realizacji tej kompetencji może być chociażby ustanowienie programu Ariane w latach 1997-1999, którego celem było wsparcie rynku książek i czytelnictwa ${ }^{12}$.

Podczas gdy sformułowania zawarte w art. 167 ust.1-3 oraz art. 167 ust. 5 TFUE nie wywołują szczególnych problemów interpretacyjnych, treść art. 167 ust. 4 TFUE jest przedmiotem kontrowersji ${ }^{13}$. Artykuł 167 ust. 4 TFUE ustanowił tzw. klauzulę kultury, która upoważnia Unię, działającą przez swoje instytucje, organy i agencje, do uwzględniania ,aspektów kulturalnych w swoim działaniu na podstawie innych postanowień traktatów, w szczególności w celu poszanowania i popierania różnorodności jej kultur”. W przeciwieństwie do pozostałych ustępów Ww. artykułu, które nie posiadają szczególnego znaczenia politycznego ${ }^{14}$, art. 167 ust. 4 TFUE zawiera normę zadaniową, która stosowana jest w interakcji z innymi

11 A. Śliwek-Ślusarek, Artykut 167, [w:] Traktat o funkcjonowaniu Unii Europejskiej. Komentarz, t. 2, red. K. Kowalik-Bańczyk, M. Szwarc-Kuczer, A. Wróbel, Warszawa 2012, s. 1034.

12 Decyzja Parlamentu Europejskiego i Rady nr 2085/97/EC z dnia 6 października 1997 r. ustanawiająca program wsparcia, łącznie z tłumaczeniem, w dziedzinie książek i czytelnictwa, $31997 \mathrm{D} 2085$.

13 V. Kitz, op. cit., s. 367.

14 Ibidem, s. 367. 
przepisami traktatów. Klauzulę kultury należałoby traktować jako specyficzne zastrzeżenie dla wszystkich polityk unijnych, które ustanawia nakaz uwzględniania interesów kulturowych państw członkowskich oraz obowiązek ochrony wspólnego dziedzictwa kulturowego ${ }^{15}$. Oznacza to, iż ma ona zastosowanie do przypadków, w których działalność Unii posiada tzw. wymiar kulturowy.

Ustanowienie klauzuli kultury nie zakończyło debaty nad relacjami Unii Europejskiej i państw członkowskich w zakresie powoływania się na ochronę różnorodności kulturowej jako wyjątku od stosowania niektórych postanowień traktatów. Klauzula ta jak dotąd nie została jednoznacznie zdefiniowana przez instytucje unijne (w tym przez Trybunał Sprawiedliwości Unii Europejskiej ${ }^{16}$ ), choć wielokrotnie była powoływana w postępowaniach toczących się przed TSUE ${ }^{17}$.

\section{KSIĄŻKA — PRZEDMIOT OPODATKOWANIA W UNII EUROPEJSKIEJ}

Kulturowa wartość książki jako towaru może usprawiedliwiać jej specjalne traktowanie w zakresie stosowania niektórych postanowień traktatów. Należy jednak podkreślić, iż podlega przede wszystkim unijnym regulacjom związanym ze swobodnym przepływem towarów na rynku wewnętrznym Unii Europejskiej, w szczególności związanych z opodatkowaniem.

\section{OBNIŻONA STAWKA PODATKU VAT NA KSIĄŻKI A REGULACJE PAŃSTW CZŁONKOWSKICH}

Państwa wspierają produkcję, dystrybucję oraz konsumpcję sztuki i dóbr kultury głównie przez zastosowanie bezpośredniego finansowania w formie grantów lub dotacji dla zainteresowanych podmiotów. Jednym z możliwych, a zarazem i niedocenionych mechanizmów kształtujących politykę kulturalną państw jest możliwość zastosowania obniżonej stawki podatku VAT dla towarów i usług kulturalnych $^{18}$.

15 M. Muszyński, Polityki Unii Europejskiej, [w:] M. Muszyński, D.E. Harasimiuk, M. Kozak, Unia Europejska: instytucje polityki, prawo, Warszawa 2012, s. 360.

16 Dalej: TSUE, Trybunał.

17 Zob. np. Wyrok TS z dnia 30 kwietnia 2009 r. w sprawie C-531/07 Fachverband der Buchund Medienwirtschaft przeciwko LIBRO Handelsgesellschaft mbH, ECLI:EU:C:2009:276; Wyrok Sądu z dnia 12 kwietnia 20013 r. w sprawie T-451/08 Föreningen Svenska Tonsättares Internationella Musikbyrå u.p.a. (Stim) przeciwko Komisji, ECLI:EU:T:2013:189.

18 K.J. Borowiecki, T. Navarrete, Fiscal and Economic Aspects of Book Consumption in the European Union, http://www.culturaleconomics.org/awp/AWP-02-2015.pdf, s. 1 (dostęp: 31.03.2016). 
Zgodnie z regulacjami UE każde państwo członkowskie jest zobowiązane do przestrzegania unijnych przepisów podatkowych uregulowanych m.in. w dyrektywie $2006 / 112 / \mathrm{WE}^{19}$. Określa ona podstawowe ramy funkcjonowania podatku od towarów i usług na terytorium Unii Europejskiej, przy czym pozostawia państwom członkowskim pewien stopień swobody w tym zakresie.

Zgodnie z postanowieniami dyrektywy państwa członkowskie zobowiązane są do ustanowienia minimalnej stawki podatku VAT w wysokości $15 \%$. Obecnie najwyższą stawką w Unii Europejskiej jest stawka na Węgrzech — 27\%. Na mocy art. 98 dyrektywy państwa członkowskie mają możliwość ustanowienia nie więcej niż dwóch obniżonych stawek obejmujących towary i usługi wymienione w załączniku III, który w pkt 6 wskazuje także książkę. Wskutek zmian wprowadzonych do dyrektywy w 2009 roku terminem tym zostały określone książki znajdujące się ,na wszystkich nośnikach fizycznych”. Zgodnie z najnowszym orzecznictwem Trybunału ${ }^{20}$ katalog ten nie obejmuje jednak e-booków, co zostanie omówione w osobnym punkcie.

Obniżona stawka podatku VAT dla książek, na której zastosowanie zezwala prawodawstwo unijne, jest wprowadzona obecnie w systemach podatkowych 26 z 28 państw członkowskich Unii Europejskiej (patrz tabela na następnej stronie ${ }^{21}$ ).

Bułgaria i Dania nie zdecydowały się na zastosowanie obniżonej stawki podatku VAT w przeciwieństwie do Irlandii oraz Wielkiej Brytanii, które objęły książki zerową stawką podatku. Państwa członkowskie mają swobodę wyboru zarówno wysokości stawki, jak i kryteriów objęcia nią danego towaru. Przykładowo, Holandia objęła książki obniżoną stawką VAT ze względu na ich kulturalne i edukacyjne wartości, Słowacja w celu zwiększenia produkcji i konsumpcji literatury napisanej w języku krajowym, co miało wpłynąć na wyższy stopień edukacji obywateli, a Szwecja - aby obniżyć ich ceny i skutecznie promować czytelnictwo ${ }^{22}$. Brak jest jednak kompleksowych badań związanych ze skutkami wprowadzenia obniżonej stawki podatku VAT dla książek w państwach członkowskich Unii Europejskiej, a dotychczasowe szczątkowe wyniki nie dostarczają jasnych wniosków w zakresie jej wpływu na osiągnięcie zakładanych rezultatów ${ }^{23}$.

19 Dyrektywa Rady nr 2006/112/WE z dnia 28 listopada 2006 r. w sprawie wspólnego systemu podatku od wartości dodanej, 32006L0112; dalej: dyrektywa VAT.

${ }^{20}$ Zob. wyrok TS z dnia 5 marca 2015 r. w sprawie C-502/13 Komisja przeciwko Luksemburgowi, ECLI:EU:C:2015:143; wyrok TS z dnia 5 marca 2015 r. w sprawie C-479/13 Komisja przeciwko Francji, ECLI:EU:C:2015:141.

${ }^{21}$ Opracowanie własne na podstawie An IPA/FEP Global Special Report on VAT/GST on Books \& E-books issued on 20 July 2015, http://www.internationalpublishers.org/images/VAT2015. pdf (dostęp: 31.03.2016).

22 K.J. Borowiecki, T. Navarrete, op. cit., s. 5.

23 Ibidem, s. 13. 
Tabela 1. Podstawowa stawka VAT w państwach członkowskich Unii Europejskiej i stawka VAT dla książek drukowanych

\begin{tabular}{|l|c|c|l|c|c|}
\hline Państwo & $\begin{array}{c}\text { Podstawowa } \\
\text { stawka VAT }\end{array}$ & $\begin{array}{c}\text { Stawka VAT } \\
\text { dla książek } \\
\text { drukowanych }\end{array}$ & Państwo & $\begin{array}{c}\text { Podstawowa } \\
\text { stawka VAT }\end{array}$ & $\begin{array}{c}\text { Stawka VAT } \\
\text { dla książek } \\
\text { drukowanych }\end{array}$ \\
\hline Austria & $20 \%$ & $10 \%$ & Litwa & $21 \%$ & $9 \%$ \\
\hline Belgia & $21 \%$ & $6 \%$ & Luksemburg & $17 \%$ & $3 \%$ \\
\hline Bułgaria & $20 \%$ & $20 \%$ & Lotwa & $21 \%$ & $12 \%$ \\
\hline Chorwacja & $25 \%$ & $5 \%$ & Malta & $18 \%$ & $5 \%$ \\
\hline Cypr & $19 \%$ & $5 \%$ & Niemcy & $19 \%$ & $7 \%$ \\
\hline Czechy & $21 \%$ & $10 \%$ & Polska & $23 \%$ & $5 \%$ \\
\hline Dania & $25 \%$ & $25 \%$ & Portugalia & $23 \%$ & $6 \%$ \\
\hline Estonia & $20 \%$ & $9 \%$ & Rumunia & $24 \%$ & $9 \%$ \\
\hline Finlandia & $24 \%$ & $10 \%$ & Słowacja & $20 \%$ & $10 \%$ \\
\hline Francja & $20 \%$ & $5,5 \%$ & Słowenia & $22 \%$ & $9,5 \%$ \\
\hline Grecja & $23 \%$ & $6,5 \%$ & Szwecja & $25 \%$ & $6 \%$ \\
\hline Hiszpania & $21 \%$ & $4 \%$ & Węgry & $27 \%$ & $5 \%$ \\
\hline Holandia & $21 \%$ & $6 \%$ & Wielka Brytania & $20 \%$ & $0 \%$ \\
\hline Irlandia & $23 \%$ & $0 \%$ & Włochy & $22 \%$ & $4 \%$ \\
\hline
\end{tabular}

Źródło: Opracowanie własne na podstawie An IPA/FEP Global...

\section{STATUS E-BOOKA W ŚWIETLE ORZECZNICTWA TRYBUNAŁU SPRAWIEDLIWOŚCI UNII EUROPEJSKIEJ}

Rewolucja cyfrowa objęła również sektor wydawniczy. E-book, powszechnie określany jako elektroniczny odpowiednik drukowanej książki ${ }^{24}$, stworzył nowe możliwości dla czytelników, którzy mają dostęp do niezliczonej ilości książek na przenośnym urządzeniu w dowolnym czasie i miejscu, a autorzy, wydawnictwa i księgarnie uzyskały nową drogę pozyskania odbiorców.

Problem związany ze statusem e-booków pojawił się w związku z jego opodatkowaniem obniżoną stawką VAT. W styczniu 2012 roku Francja i Luksemburg objęły książki elektroniczne obniżoną stawką podatku od towarów i usług, dowodząc, że termin „książka [znajdująca się] na wszystkich nośnikach fizycznych” obejmuje również e-booki ${ }^{25}$. Stanowisko to spotkało się ze sprzeciwem Komisji,

24 E-Books: Evolving markets and new challenges - Briefing of the European Parliament Research Service, http://www.europarl.europa.eu/RegData/etudes/BRIE/2016/577954/EPRS_BRI (2016)577954_EN.pdf, s. 7 (dostęp: 31.03.2016).

25 T. Colbjørnsen et al., Book - At what price? Raport on policy instruments in the publishing industry in Europe, http://www.europeanbooksellers.eu/wp-content/uploads/2015/03/Books-atwhich-Price.pdf, s. 46 (dostęp: 31.03.2016). 
która podkreśliła, iż pobieranie e-booka stanowi usługę świadczoną elektronicznie i tym samym nie należy do katalogu wymienionym w załączniku III dyrektywy VAT. Wskutek braku porozumienia między Komisją a Francją i Luksemburgiem sprawa trafiła do Trybunału.

Trybunał w wyrokach z dnia 5 marca 2015 roku $^{26}$ przychylił się do stanowiska Komisji ${ }^{27}$ oraz odrzucił argumentację Francji i Luksemburga opierającą się na przekonaniu, że pkt 6 załącznika III do dyrektywy VAT obejmuje dostawę e-booków i tym samym zezwala na objęcie ich obniżoną stawką podatku. Ponadto stwierdził, że konstrukcja ww. przepisu dopuszcza zastosowanie obniżonej stawki podatku tylko do dostawy książek znajdujących się na jakimkolwiek nośniku fizycznym, co wyklucza zastosowanie go do książek elektronicznych, które stanowią usługę świadczoną drogą elektroniczną ${ }^{28}$. Wskutek wyroku Luksemburg przywrócił podstawową stawkę VAT na książki elektroniczne od 1 maja 2015 roku, podczas gdy Francja zdecydowała się utrzymać obniżoną stawkę w mocy do końca 2016 roku $^{29}$. Obecnie jedynie Włochy stosują obniżoną stawkę VAT w stosunku do książek elektronicznych (nie były adresatem wyroku Trybunału w tej sprawie) i nie ma aktualnie informacji dotyczących planów włoskiego rządu w tym zakresie ${ }^{30}$.

Wskutek wyroku Trybunału ministrowie kultury Francji, Niemiec, Polski i Włoch skierowali do Komisji wspólną deklarację, w której wzywają do zmian w unijnym prawodawstwie związanym z możliwością zastosowania obniżonej stawki podatku VAT dla e-booków ponieważ „książka jest książką niezależnie od tego jaką ma formę"31. Wątpliwości co do zasadności zróżnicowania stawek podatku VAT dla książek papierowych i elektronicznych zostały także zaprezentowane w postępowaniu toczącym się od 2013 roku przed polskim Trybunałem Konstytucyjnym. W lipcu 2015 roku skierował on pytanie prejudycjalne do TSUE dotyczące m.in. naruszenia zasady neutralności podatkowej w zakresie, w jakim wyłącza stosowanie obniżonych stawek podatku do książek wydawanych w formie cyfrowej i innych publikacji elektronicznych ${ }^{32}$. Niezależnie od toczącego się postępowania przed TSUE, Komisja zobowiązała się zrewidować unijny system podatku VAT w 2016 roku $^{33}$.

\footnotetext{
26 Wyroki TS z dnia 5 marca 2015 r. w sprawie C-502/13 oraz C-479/13.

27 Por. np. pkt. 36-38 wyroku TS w sprawie C-502/13.

28 Por. np. pkt. 40-41 wyroku TS w sprawie C-502/13.

29 E-Books: Evolving markets..., s. 9.

30 Ibidem.
}

31 Wspólna Deklaracja Ministrów Kultury Francji, Niemiec, Polski i Włoch dotycząca podatku VAT na e-książki, http://www.mkidn.gov.pl/media/docs/2015/20150320_deklaracja_pl.pdf(dostęp: 31.03.2016).

32 Postanowienie Trybunału Konstytucyjnego z dnia 7 lipca 2015 r., Sygn. akt K 61/13, OTK ZU nr 7A/2015, poz. 103.

33 An IPA/FEP Global Special..., s. 7. 


\section{PRAWO AUTORSKIE I PRAWA POKREWNE A OCHRONA KSIĄŻEK}

Unijna ochrona prawa autorskiego i praw pokrewnych nierozerwanie związana jest $\mathrm{z}$ zasadą swobodnego przepływu towarów. Zgodnie z art. 36 TFUE ochrona własności przemysłowej i handlowej może stanowić uzasadnienie dla stosowania zakazów lub ograniczeń przewozowych, wywozowych lub tranzy towych w Unii Europejskiej. Ze względu na to, iż TFUE nie zdefiniował pojęcia „własności przemysłowej i handlowej", jego interpretacja powodowała wiele problemów ${ }^{34}$. Zgodnie z orzecznictwem TSUE pojęcie to rozciąga się również na ochronę przyznaną prawem autorskim ${ }^{35}$. Wskutek wąskiej interpretacji wyłączeń od swobód rynku wewnętrznego prezentowanej przez Trybunał istotne w tym kontekście może być powołanie się na klauzulę kultury jako uzasadnienie specjalnej ochrony niektórych przedmiotów prawa autorskiego ${ }^{36}$. Jej zastosowanie stało się przedmiotem postępowania przed TSUE, który podkreślił w tym kontekście znaczenie art. 167 TFUE (wtedy: art. 128 TWE), stwierdzając, iż jego celem jest wspieranie artystycznej i literackiej twórczości ${ }^{37}$.

Ochrona własności intelektualnej została także potwierdzona w art. 17 ust. 2 Karty Praw Podstawowych Unii Europejskiej. Zgodnie z Wyjaśnieniami do Karty pojęcie to obejmuje również własność literacką i artystyczną ${ }^{38}$.

\section{UMOWY MIĘDZYNARODOWE DOTYCZĄCE PRAW AUTORSKICH I POKREWNYCH ORAZ ICH MIEJSCE W PRAWIE UNII EUROPEJSKIEJ}

W zakresie prawa autorskiego i praw pokrewnych mamy do czynienia z rozbudowanym międzynarodowym systemem ich ochrony ${ }^{39}$. Niemniej tylko niektó-

34 A. Auleyter, Ochrona praw autorskich i pokrewnych a zasady swobodnego przeptywu towarów i świadczenia usług w Unii Europejskiej, Warszawa 2016, s. 10.

35 Wyrok TS z dnia z 20 stycznia 1981 w połączonych sprawach 55/80 i 57/80 Musik-Vertrieb membran GmbH and K-tel International v GEMA - Gesellschaft für musikalische Aufführungs- und mechanische Vervielfältigungsrechte, ECLI:EU:C:1981:10, pkt 9.

36 V. Kitz, op. cit., s. 382.

37 Wyrok TS z dnia 28 kwietnia 1998 r. w sprawie C-200/96 Metronome Musik GmbHv Music Point Hokamp GmbH, ECLI:EU:C:1998:172, pkt. 28.

38 Wyjaśnienia dotyczące Karty Praw Podstawowych, 32007X1214(01).

39 Konwencja berneńska o ochronie dzieł literackich i artystycznych z dnia 9 września 1886 r., przejrzana w Berlinie dnia 13 listopada 1908 r. i w Rzymie dnia 2 czerwca 1928 r. (Dz.U. 1935, Nr 84, poz. 515); Międzynarodowa konwencja o ochronie wykonawców, producentów fonogramów oraz organizacji nadawczych, sporządzona w Rzymie dnia 26 października 1961 r. (Dz.U. 1997, Nr 125, poz. 800); Powszechna Konwencja o prawie autorskim zrewidowana w Paryżu dnia 24 lipca 1971 r. (Dz.U. 1978, Nr 8, poz. 28); Konwencja genewska o ochronie producentów fonogramów przed ich niedozwolonym powielaniem zawarta 29 października 1971 r., Seria Traktatów Organizacji Narodów Zjednoczonych, t. 866, Nr 12430, s. 67; Konwencja brukselska dotycząca rozpowszechniania sygnału programu przekazywanego za pośrednictwem satelity zawarta dnia 21 maja 1974 r., Seria Traktatów Organizacji Narodów Zjednoczonych, t. 1144, Nr 17949, s. 3; Porozumienie w sprawie handlowych 
re $\mathrm{z}$ tych umów należą do katalogu źródeł unijnego prawa ${ }^{40}$. Mimo to nawet te konwencje, które nie stanowią źródeł prawa UE, mogą mieć istotne znaczenie dla interpretacji unijnych przepisów, w tym dla praktyki orzeczniczej ${ }^{41}$.

Niektóre z konwencji z zakresu prawa autorskiego ${ }^{42}$ zostały zawarte przed utworzeniem Wspólnot Europejskich bądź przed przystąpieniem do nich przez poszczególne państwa — strony. W związku z tym nie stanowią one źródła prawa unijnego, choć państwa członkowskie - strony konwencji zobowiązane są do ich przestrzegania. Niezbędne okazało się określenie stosunku przepisów tychże konwencji do postanowień traktatów, co zostało dokonane w art. 351 TFUE.

Co do zasady — wszystkie państwa członkowskie Unii Europejskiej są związane wyżej wymienionymi umowami międzynarodowymi, chociaż np. Malta nie jest stroną konwencji rzymskiej, konwencji genewskiej i konwencji brukselskiej, a Polska nie przystąpiła do dwóch ostatnich. W 1991 roku Komisja wezwała wszystkie państwa członkowskie do przystąpienia do konwencji berneńskiej oraz konwencji rzymskiej do 31 grudnia 1992 roku $^{43}$. Wezwanie to zostało powtórzone przez radę w rezolucji z 1992 roku $^{44}$. Obecnie wszystkie państwa członkowskie są stronami konwencji berneńskiej w przeciwieństwie do konwencji rzymskiej, do której nie przystąpiła tylko Malta. Wezwania Unii do przystąpienia do powyższych konwencji miały miejsce przed rozszerzeniem UE w 2004 roku i nie zostały później powtórzone.

Przystąpienie Unii Europejskiej do Traktatu WIPO o prawie autorskim miało istotne znaczenie dla określenia miejsca konwencji berneńskiej w systemie prawa unijnego ${ }^{45}$. Konwencja berneńska jako umowa otwarta do podpisu tylko dla państw nie przewiduje możliwości, by jej stroną była organizacja międzynarodowa. Zgodnie z art. 1 ust. 4 Traktatu WIPO o prawie autorskim ,[u]mawiające się strony [w tym Unia Europejska i państwa członkowskie] zastosują się do art.1-24 oraz załącznika do Konwencji berneńskiej”. Wynika z tego, iż Unia Europejska zobowiązana jest do stosowania jej postanowień, mimo iż de facto nie jest jej stroną ${ }^{46}$.

aspektów praw własności intelektualnej (TRIPS) stanowiące załącznik nr 1 do Porozumienia ustanawiającego Światową Organizację Handlu (WTO) (Dz.U. 1996 Nr 32, poz. 143); Traktat Światowej Organizacji Własności Intelektualnej (WIPO) o artystycznych wykonaniach i fonogramach, sporządzony w Genewie dnia 20 grudnia 1996 r. (Dz.U. 2004 Nr 41, poz. 375); Traktat Światowej Organizacji Własności Intelektualnej (WIPO) o prawie autorskim sporządzony w Genewie dnia 20 grudnia 1996 r. (Dz.U. 2005 Nr 3, poz. 12).

40 Tj. Porozumienie TRIPS, Traktat WIPO o artystycznych wykonaniach i fonogramach, Traktat WIPO o prawie autorskim oraz Traktat WIPO o artystycznych wykonaniach audiowizualnych.

41 A. Auleytner, op. cit., s. 29.

$42 \mathrm{Tj}$. konwencja berneńska, konwencja powszechna, konwencja rzymska oraz konwencja genewska.

43 Follow up to the Green Paper, Working programme of the Commission in the field of copyright and neighbouring rights, 51990DC0584, s. 6.

44 Rezolucja Rady nr 138/01 z 14 maja 1992 r. o zwiększonej ochronie praw autorskich i pokrewnych, 31992Y0528(01).

45 A. Auleytner, op. cit., s. 32.

46 T. Dreier, B. Hugenholtz, Concise European Copyright Law, London 2006, s. 91. 
Podobne zobowiązanie UE do stosowania art. 1-21 konwencji berneńskiej wynika również z art. 9 ust. 1 Porozumienia TRIPS, którego Unia jest stroną ${ }^{47}$. Należy jednak zauważyć, że zakres zobowiązania UE wynikający z Porozumienia TRIPS jest węższy niż zakres wynikający z Traktatu WIPO o prawie autorskim, gdyż na mocy Porozumienia TRIPS członkom Międzynarodowej Organizacji Handlu nie przysługują prawa ani nie powstają w stosunku do nich obowiązki związane $\mathrm{z}$ autorskimi prawami osobistymi lub prawami z nich wynikłymi. Zakres zobowiązania UE do stosowania wybranych postanowień konwencji berneńskiej został potwierdzony również w orzecznictwie Trybunału ${ }^{48}$.

Przeważająca część państw członkowskich związana jest umowami, które zostały przez nie podpisane po przystąpieniu do Unii Europejskiej. Wśród nich znajdują się: konwencja rzymska, powszechna, genewska oraz brukselska. Unia Europejska nie jest stroną wyżej wymienionych konwencji ze względu na to, że tak jak konwencja berneńska, są one otwarte do podpisu wyłącznie dla państw. $Z$ tego względu żadna z powyższych konwencji nie jest częścią porządku prawnego Unii, gdyż nie ma umocowania $\mathrm{w}$ traktatach.

Unia Europejska ma jednak kompetencję do samodzielnego zawierania umów międzynarodowych z podmiotami trzecimi, które zgodnie z przepisami TFUE stanowią źródło prawa UE i są integralną częścią unijnego porządku prawnego. Do dnia dzisiejszego UE zawarła samodzielnie jedynie dwie umowy międzynarodowe - Traktaty WIPO z 1996 roku — oraz jest sygnatariuszem dwóch umów mieszanych - Porozumienia TRIPS oraz Traktatu WIPO o artystycznych wykonaniach audiowizualnych z 2012 roku (traktat ten nie wszedł jeszcze w życie) ${ }^{49}$. Są one wiążące dla instytucji Unii oraz państw członkowskich, a także stanowią część porządku prawnego Unii Europejskiej ${ }^{50}$.

47 A. Auleytner, op. cit., s. 33.

48 Zob. Wyrok TS z dnia 9 lutego 2012 r. w sprawie C-277/10 Martin Luksan przeciwko Petrusowi van del Letowi, ECLI:EU:C:2012:65, pkt 59 oraz wyrok TS z dnia 4 października $2011 \mathrm{r}$. w połączonych sprawach C-403/08 i C-429/08 Football Association Premier League Ltd i inni przeciwko QC Leisure i innym, ECLI:EU:C:2011:631, pkt 189.

49 Zob. Decyzja Rady nr 94/800/WE z dnia 22 grudnia 1994 r. dotycząca zawarcia w imieniu Wspólnoty Europejskiej w dziedzinach wschodzących w zakres jej kompetencji, porozumień będących wynikiem negocjacji wielostronnych w ramach Rundy Urugwajskiej (1986-1994), 31994D0800; Decyzja Rady nr 2000/27/WE z dnia 16 marca 2000 r. w sprawie zatwierdzenia w imieniu Wspólnoty Europejskiej Traktatu WIPO o prawach autorskich oraz Traktatu WIPO o artystycznych wykonaniach i fonogramach, 32000D0278; Decyzja Rady nr 2013/275/UE z dnia 10 czerwca 2013 r. w sprawie podpisania w imieniu Unii Europejskiej traktatu pekińskiego o artystycznych wykonaniach audiowizualnych, 32013D0275.

50 Wyrok TS z dnia 15 marca 2012 r. w sprawie C-135/10 Società Consortile Fonografici (SCF) przeciwko Marco Del Corso, ECLI:EU:C:2012:140, pkt 38. 


\section{UNIJNA OCHRONA PRAWA AUTORSKIEGO I PRAW POKREWNYCH}

W procesie harmonizowania prawa autorskiego w Unii Europejskiej wysiłki legislacyjne skupiły się w większości na zbliżeniu reguł dotyczących korzystania z praw majątkowych, co poskutkowało wydaniem 10 dyrektyw ${ }^{51}$. Należy jednak zaznaczyć, że nie obejmują one ochrony autorskich praw osobistych, które wykonywane są zgodnie z ustawodawstwami państw członkowskich i postanowieniami Konwencji berneńskiej.

W zakresie ochrony prawa autorskiego unijne regulacje nie zostały jeszcze w pełni zharmonizowane z uwagi na brak ujednoliconych wymagań co do poziomu oryginalności działa ${ }^{52}$. Wskutek odmiennych przepisów państw członkowskich w tej materii możliwe jest występowanie przeszkód w wewnątrzunijnym handlu, co zostało potwierdzone przez Komisję ${ }^{53}$. Należy jednak zaznaczyć, iż zgodnie z opinią Komisji w tej sprawie nie ma wskazań, aby brak harmonizacji co do pojęcia oryginalności stanowił problem dla funkcjonowania rynku wewnętrznego w odniesieniu do kategorii dzieł takich, jak kompozycje, filmy czy książki ${ }^{54}$.

Zgodnie $\mathrm{z}$ orzecznictwem Trybunału ${ }^{55}$ unijny system ochrony praw autorskich opiera się na przesłance oryginalności utworu ustanowionej w konwencji

51 Dyrektywa Rady nr 93/83/EWG z dnia 27 września 1993 r. w sprawie koordynacji niektórych zasad dotyczących prawa autorskiego oraz praw pokrewnych stosowanych w odniesieniu do przekazu satelitarnego oraz retransmisji drogą kablową, 31993L0083; Dyrektywa nr 96/9/WE Parlamentu Europejskiego i Rady z dnia 11 marca 1996 r. w sprawie ochrony prawnej baz danych, 31996L0009; Dyrektywa nr 2001/29/WE Parlamentu Europejskiego i Rady z dnia 22 maja 2001 r. w sprawie harmonizacji niektórych aspektów praw autorskich i pokrewnych w społeczeństwie informacyjnym, 32001L0029; Dyrektywa nr 2001/84/WE Parlamentu Europejskiego i Rady z dnia 27 września $2001 \mathrm{r}$. w sprawie prawa autora do wynagrodzenia z tytułu odsprzedaży oryginalnego egzemplarza dzieła sztuki, 32001L0084; Dyrektywa nr 2004/48/WE Parlamentu Europejskiego i Rady z dnia 29 kwietnia 2004 r. w sprawie egzekwowania praw własności intelektualnej, 32004L0048R(01); Dyrektywa nr 2006/116/WE Parlamentu Europejskiego i Rady z dnia 12 grudnia 2006 r. w sprawie czasu ochrony prawa autorskiego i niektórych praw pokrewnych, 32011L0077; Dyrektywa nr 2006/115/WE Parlamentu Europejskiego i Rady z dnia 12 grudnia 2006 r. w sprawie prawa najmu i użyczenia oraz niektórych praw pokrewnych prawu autorskiemu w zakresie własności intelektualnej, 32006L0115; Dyrektywa Parlamentu Europejskiego i Rady nr 2009/24/WE z dnia 23 kwietnia 2009 r. w sprawie ochrony prawnej programów komputerowych, 32009L0024; Dyrektywa Parlamentu Europejskiego i Rady nr 2012/28/UE z dnia 25 października 2012 r. w sprawie niektórych dozwolonych sposobów korzystania z utworów osieroconych, 32012L0028; Dyrektywa Parlamentu Europejskiego i Rady nr 2014/26/UE z dnia 26 lutego 2014 r. w sprawie zbiorowego zarządzania prawami autorskimi i prawami pokrewnymi oraz udzielania licencji wieloterytorialnych dotyczących praw do utworów muzycznych do korzystania online na rynku wewnętrznym; 32014L0026; A. Auleytner, op. cit., s. 61.

52 Ibidem, s. 62.

53 Zob. Commission Staff Working Paper on the review of the EC legal framework in the field of copyright and related rights issued on 19 July 2004, http://ec.europa.eu/internal_market/copyright/ docs/review/sec-2004-995_en.pdf (dostęp: 31.03.2016).

54 Ibidem, s. 14.

55 Wyrok TS z dnia 16 lipca 2007 r. w sprawie C 5/08 Infopaq International A/S przeciwko Danske Dagblades Forening, ECLI:EU:C:2009:465, pkt 34-39. 
berneńskiej, która na mocy art. 2 obejmuje również książki jako dzieła literackie i artystyczne. Ponadto art. 1 dyrektywy 2006/116/WE określa, iż prawa autora do nich co do zasady podlegają ochronie w okresie życia autora i przez okres 70 lat, licząc od dnia jego śmierci, a w przypadku utworów anonimowych lub utworów, przy których posłużono się pseudonimem, czas ten wynosi 70 lat od dnia zgodnego z prawem podania utworu do publicznej wiadomości. Jest to czas dłuższy niż przyznany na mocy art. 7 Konwencji berneńskiej obejmujący co do zasady 50 lat.

Unijna ochrona prawa autorskiego i praw pokrewnych opiera się także na zasadzie terytorialności, która uzależnia ochronę przyznaną autorom od regulacji prawnych państwa, w którym prawa te są wykonywane. Ponadto ustawodawstwo zagraniczne nie ma zastosowania $\mathrm{w}$ razie wykonywania ich w kraju, w którym takiej ochrony się dochodzi ${ }^{56}$. W celu korzystania z przedmiotu prawa autorskiego lub pokrewnego na obszarze większym niż obszar jednego kraju (co ma częste zastosowanie w przypadku obszaru Unii Europejskiej) niezbędne jest uzyskanie licencji na terytorium każdego dodatkowego państwa. Należy przy tym podkreślić, że prawa te zazwyczaj wykonywane są w imieniu uprawnionych przez organizacje zbiorowego zarządzania, których zakres działania obejmuje tylko terytorium jednego państwa. W związku z tym często konieczne jest zawarcie odrębnej umowy z poszczególnymi organizacjami właściwymi dla danego terytorium ${ }^{57}$. Polskim przykładem organizacji zbiorowego zarządzania prawami autorskimi, która działa na rzecz wydawców książek, jest Stowarzyszenie Autorów i Wydawców Copyright Polska.

Zasada terytorializmu prawa autorskiego i praw pokrewnych spotkała się z krytyką Komisji Europejskiej, która zmierza do stworzenia rynku wewnętrznego obejmującego również swobodę przepływu podmiotów ochrony prawa autorskiego i praw pokrewnych ${ }^{58}$. Należy jednak podkreślić, iż ma szczególne znaczenie dla zachowania różnorodności kulturowej państw członkowskich przez wymóg uzyskania odrębnych licencji, który skutkuje koniecznością oddzielnych negocjacji co do uwzględniania odrębności narodowych ${ }^{59}$.

\section{STAŁA CENA KSIĄŻKI W UNII EUROPEJSKIEJ}

Ustanowienie stałej ceny książki ma długą tradycję w europejskich państwach. Głównym celem jej wprowadzenia jest uznanie cennego wkładu książki do zachowania, rozpowszechniania, kształtowania i rozwijania kultury narodowej.

56 A. Auleytner, op. cit., s. 14.

57 Ibidem, s. 15.

58 Green Paper on Copyright and the Challange of Technology - Copyright Issues Requiring Immediate Action issued on 7 June 1988, 51988DC0172, s. 10.

59 A. Auleytner, op. cit., s. 18. 
Należy także zaznaczyć, iż to właśnie ochrona wartości ekonomicznych i kulturowych książki służy usprawiedliwieniu jej specjalnego traktowania chociażby w przypadku stosowania reguł konkurencji.

\section{DWA REŻIMY W EUROPIE - FIXED BOOK PRICE AGREEMENT ORAZ FIXED BOOK PRICE LAW}

Regulacje prawne związane ze stałą ceną książki mogą przybierać różne formy, niemniej jednak opierają się na dwóch podstawowych rozwiązaniach: ogólnokrajowego prawa (Fixed Book Price Law, dalej: FBPL) lub umowach handlowych zawartych między wydawnictwami a księgarniami (Fixed Book Price Agreement, dalej: FBPA). Rozwiązania te mogą różnić się czasowym (jak długo od wydania stała cena książki powinna być stosowana) i przedmiotowym zakresem obowiązywania (kwestią, czy obejmuje np. e-booki, podręczniki szkolne), a także możliwością zastosowania wyjątków związanych z udzielaniem promocji wybranym podmiotom (np. bibliotekom albo instytucjom naukowym) ${ }^{60}$.

Początkowo, aby regulować cenę książek, stosowana była metoda umów zawieranych między wydawnictwami a księgarniami (np. Net Book Agreement w Wielkiej Brytanii zniesiona w 1995 roku). Natomiast pierwszym państwem, które wprowadziło wewnętrzną regulację dotyczącą ustalenia stałej książki była Francja w 1981 roku (tzw. Loi Lang). Obecnie większość państw członkowskich, które regulują stałą cenę książki, stosuje tę ostatnią metodę ${ }^{61}$.

\section{PRAWO UNII EUROPEJSKIEJ A STAŁA CENA KSIĄŻKI}

Problem stosowania prawa Unii Europejskiej w zakresie stałej ceny książki pojawia się w przypadku handlu transgranicznego między państwami. Zgodnie $\mathrm{z}$ art. 101 TFUE zakazane są wszelkie porozumienia między przedsiębiorstwami, które mogą wpłynąć na handel między państwami członkowskimi, a których celem jest zapobieżenie, ograniczenie lub zakłócenie konkurencji wewnątrz rynku wewnętrznego. Może ono polegać m.in. na ustalaniu w sposób bezpośredni lub pośredni cen zakupu lub sprzedaży. Zatem tak długo jak stała cena książki ustalona jest wyłącznie w obrębie jednego państwa członkowskiego oraz nie wpływa ona na handel między nim a innymi państwami członkowskimi, prawo Unii Europejskiej nie ma zastosowania. Niemniej jednak transgraniczne umowy, o których mowa w ww. artykule, związane z ustaleniem stałej ceny książki, są nadal aktualnym problemem. Niektóre sąsiadujące z sobą państwa dzielą ten sam obszar językowy,

60 Global Fixed Book Price Report of International Publishers Association issued on 23 May 2014, http://www.internationalpublishers.org/images/reports/2014/fixed-book-price-report-2014.pdf, s. 1 (dostęp: 31.03.2016).

61 Np. Austria, Hiszpania, Holandia, Niemcy. 
co wpływa na powiązanie struktur rynków wydawniczych na ich terytorium ${ }^{62}$, a tym samym powoduje niemożność wprowadzenia regulacji dotyczących stałej ceny książki.

Przez wiele lat państwa członkowskie z powodzeniem realizowały politykę stałej ceny książki w formie FBPA lub FBPL, nie łamiąc przy tym prawa unijnego. Problem pojawił się dopiero w 1995 roku wskutek przystąpienia Austrii do Unii Europejskiej. W 1993 roku austriaccy, niemieccy i szwajcarscy wydawcy zawarli między sobą wzajemne umowy dotyczące ustalenia stałej ceny książki na terytorium obejmującym ich obszar językowy, a z datą przystąpienia Austrii do UE materia ta została przedmiotem unijnego prawa antymonopolowego zakazującego takich praktyk ${ }^{63}$. Sprawa stała się przedmiotem postępowania prowadzonego przez Komisję, podczas którego obie strony zgodziły się, iż zawarta umowa narusza obecny art. 101 TFUE (dawniej: art. 81 TWE). Niemniej powstało pytanie dotyczące zastosowania klauzuli kultury jako możliwości usprawiedliwienia wyjątku od tego przepisu, które było oparte na potrzebie ochrony szczególnej wartości kulturowej książki ${ }^{64}$. Problem zastosowania klauzuli kultury w tej sprawie nie został jednak rozwiązany wskutek porozumienia zawartego między stronami. Austriaccy i niemieccy wydawcy zdecydowali o zaprzestaniu stosowania transgranicznej umowy przy jednoczesnym zachowaniu osobnych systemów dotyczących stałej ceny książki w każdym z państw, podczas gdy Komisja zasygnalizowała, iż nie będzie ingerowała $\mathrm{w}$ tę praktykę ${ }^{65}$. Ze względu na zawarte porozumienie Trybunał nie miał szansy wypowiedzieć się w tej sprawie i skomentować zasadności zastosowania tej klauzuli w tym przypadku.

Mimo iż unijne prawo antymonopolowe zakazuje praktyk związanych z wprowadzeniem stałej ceny książki obejmującej terytorium więcej niż jednego państwa członkowskiego, Unia Europejska nie pozostaje bierna w tym zakresie. Już w 1981 roku Parlament, oprócz zwrócenia uwagi na unikatową wartość książki jako przedmiotu transakcji i kultury, podkreślił, że ma ona szczególne znaczenie dla kulturowej tożsamości Europy ${ }^{66}$. Ponadto wskazał, iż liberalizacja cen mogąca pomóc udostępnieniu książek szerokiej grupie odbiorców może mieć ekonomiczne konsekwencje szkodliwe dla mniejszości konsumentów (np. spadek liczby wydawanych tytułów). Parlament zażądał również od Komisji przedstawienia koniecznych propozycji w zakresie cen książek, która doceniłaby ich unikalną rolę jako instrumentu edukacyjnego i kulturalnego. Wskutek przeprowadzonych

62 Mowa o trzech grupach państw: Austria i Niemcy, Belgia i Holandia oraz Irlandia i Wielka Brytania.

63 V. Kitz, op. cit., s. 375.

64 Written question by Michl Ebner (PPE-DE) and Doris Pack (PPE-DE) to the Commission issued on 1 September 1999, pkt 2, http://www.europarl.europa.eu/sides/getDoc.do?pubRef=-//EP// TEXT+WQ+E-1999-1400+0+DOC+XML+V0//EN\&language=sl (dostęp: 31.03.2016).

65 V. Kitz, op. cit., s. 381.

66 Rezolucja Parlamentu Europejskiego z dnia 13 lutego 1981 r. 
badań Komisja odnotowała, iż ustanowienie przepisów dotyczących książek jest utrudnione przez wzgląd na ich podwójną naturę — produktów kultury, a zarazem przedmiotów transakcji ${ }^{67}$. Natomiast Rada w decyzji z 1997 roku $^{68}$ zauważyła, jak istotne znaczenie dla niektórych państw członkowskich mają systemy stałych cen książek jako środków podtrzymywania oraz promowania różnorodności i szerokiego do nich dostępu. Wyraziła także opinię, iż przyjmowanie przez państwa członkowskie regulacji dotyczących stałych cen książek w jednolitym obszarze językowym jest dopuszczalne pod warunkiem, że ustalenia te dotyczą wyłącznie tego obszaru i wyłącznie wydań publikowanych w danym języku. Co więcej, Rada zachęciła Komisję do badania krajowych zasad i umów dotyczących stałych cen książek w zakresie, w jakim mogą wpływać na wymianę handlową między państwami członkowskimi, a także zwracania uwagi na konsekwencje rozwoju e-handlu ${ }^{69}$. Mimo braku przyjęcia do dnia dzisiejszego unijnych regulacji dotyczących stałych cen książek, co świadczy o złożoności tego problemu, dotychczasowe działania instytucji europejskich dążące do uwspólnotowienia tej dziedziny można poczytywać za sukces ${ }^{70}$.

\section{WNIOSKI}

Książka ma szczególne znaczenie dla zachowania różnorodności kulturowej w Unii Europejskiej. Choć każde państwo członkowskie ma prawo swobodnego wyboru środków służących promocji książek i czytelnictwa, działania te mogą być również uzupełniane przez unijną aktywność w tym zakresie. Podwójny charakter książki jako nośnika wartości kulturowych, a zarazem przedmiotu transakcji spowodował, iż została ona objęta specjalnymi mechanizmami wsparcia i ochrony na terytorium Unii Europejskiej.

Szczególna wartość książki jako dzieła kultury powinna być uwzględniana w przypadku stosowania niektórych postanowień traktatów. Zgodnie z unijnymi przepisami podatkowymi państwa członkowie mają możliwość zastosowania do książek obniżonej stawki podatku VAT. Z tego katalogu wyłączone są jednak e-booki, które jako usługi świadczone elektronicznie nie mogą zostać objęte takimi regulacjami.

Wartość kulturowa książki, niezależnie od jej formy i nośnika, chroniona jest także przez unijne regulacje z zakresu prawa autorskiego i praw pokrewnych

67 Por. m.in. Komunikat Komisji do Rady z dnia 29 maja 1985 r. w sprawie stworzenia wspólnotowego ramowego systemu cen książek, 51989DC0258.

68 Decyzja Rady nr 305/02 z dnia 22 września 1997 r. w sprawie ponadgranicznych stałych cenach książek w europejskich obszarach językowych, 31997D1007(02).

69 Rezolucja Rady nr 73/03 z dnia 12 lutego 2001 r...

70 A. Littoz-Monnet, The European Union and Culture. Between Economic Regulation and European Cultural Policy, New York 2007, s. 101. 
opierających się na zasadzie terytorializmu. Brak pełnej harmonizacji tej dziedziny ma szczególne znaczenie dla zachowania różnorodności kulturowej w Unii Europejskiej, a obowiązek uzyskania osobnych licencji na terytorium każdego państwa członkowskiego skutkuje uwzględnianiem odrębności narodowych.

Ochrona wartości ekonomicznych i kulturowych książki służy jej specjalnemu traktowaniu także w przypadku stosowania reguł konkurencji. Jednak system stałych cen książek obejmujący terytorium państw członkowskich dzielących ten sam obszar językowy został uznany za ich naruszenie. Jego stosowanie zostało ograniczone wyłącznie do możliwości ustanowienia krajowych regulacji, choć poszczególne instytucje UE dopuściły pod pewnymi warunkami możliwość objęcia stałą ceną książki jednolitego obszaru językowego.

Dotychczasowo wypracowane rozwiązania z pewnością przyczyniły się do uznania cennego wkładu książki w zakresie zachowania, rozpowszechniania i kształtowania kultury narodowej w państwach członkowskich. Niemniej w dobie postępującej rewolucji cyfrowej, a także erze globalizacji, niektóre z nich okazały się niewystarczające i wymagające zrewidowania.

\title{
THE BOOK AS AN OBJECT OF CULTURAL VALUE IN THE EUROPEAN UNION
}

\begin{abstract}
Summary
Books play a significant role in the preservation of cultural diversity within the European Union. Because of the binary character of the book as a cultural artifact, as well as an object of commerce, books are encompassed by special mechanisms of support and protection within the borders of the European Union. Their cultural value may also justify the unique treatment of books in the application of some of the provisions of the Treaties, e.g. in the areas of taxation, copyrights and competition law. Due to the EU legislation in the fields of VAT tax as well as copyrights, the Member States are able to highlight the valuable contribution of books concerning preservation, dissemination and development of national cultures. However, in the era of digital revolution, some of presented provisions are insufficient. Reduced rate of VAT tax cannot be applied to e-books, which were recognized by the Court of Justice of the European Union as electronically supplied services. Moreover, there is still lack of announced EU provisions on fixed book price. As a result, the Member States sharing the same language, are not able to establish joint fixed book price without breaking the European Union law.
\end{abstract}

